\title{
The "Anthropocene" uncovered
}

\author{
V. RULL \\ Institute of Earth Sciences Jaume Almera (ICTJA-CSIC), c. Lluís Solé i Sabarís, s/n, ES-08028 Barcelona, Spain
}

ORCID iD. V. RULL: http://orcid.org/0000-0002-9961-105X

E-mail: vrull@ictja.csic.es

Editor: J. López-Pujol

Received 30 May 2017; accepted 14 June 2017; published on line 12 September 2017

\begin{abstract}
THE "ANTHROPOCENE" unCOVERED. - The "Anthropocene", defined as a new geological epoch characterized by the global human footprint on Earth System, has become a term frequently used in a varied range of fields. However, some fundamental misconceptions remain on the origin and the scientific validity of this term. A common misconception is that the "Anthropocene" term and concept originated at the beginning of this century but the truth is that the concept was fully developed more than 140 years ago. Another frequent fallacy is that the "Anthropocene" is already a formal geological term. However, the process of its formalization as a new unit of the Geological Time Scale has not even begun. Another poorly addressed aspect is the significance of future human developments, from both cultural and evolutionary points of view, in the eventual definition of a new geological epoch as the "Anthropocene". This essay discusses these aspects for a non-specialized audience. The potential consequences of the uncontrolled human pressure on Earth System and the need for redressing our relationship with the planet are not under discussion. This essay is concerned only with the initiative of using this argument to propose that we have entered a new epoch of the Geological Time Scale.
\end{abstract}

Key words: Anthropocene; anthropogenic forcing; Anthropozoic; Geological Time Scale; human footprint; stratigraphy.

\section{Resumen}

EL "ANTROPOCENO" AL DESNUDO.- El "Antropoceno", definido como una nueva época geológica caracterizada por la huella humana global sobre el Sistema Tierra, se ha convertido en un término muy usado en una gran variedad de disciplinas. Sin embargo, todavía hay una serie de ideas equivocadas sobre el origen y la validez científica de este término. Un error muy común es pensar que el término y el concepto de "Antropoceno" se originaron a principios de este siglo, pero la verdad es que este concepto ya estaba plenamente desarrollado hace más de 140 años. Otra equivocación frecuente es considerar que el "Antropoceno" ya es un término geológico formal, cuando la realidad es que el proceso de su formalización como una nueva época de la Escala del Tiempo Geológico ni siquiera ha empezado. Otro aspecto muy poco tratado es la importancia del futuro cultural y evolutivo de nuestra especie en la eventual definición de una nueva época geológica como el "Antropoceno". En este ensayo se discuten estos aspectos para una audiencia no especializada. Las posibles consecuencias de la presión humana incontrolada sobre el Sistema Tierra y la necesidad de reconsiderar nuestra relación con el planeta no se discuten aquí. El ensayo está centrado, únicamente, en la utilización de este argumento para proponer que hemos entrado en una nueva época de la Escala del Tiempo Geológico.

Palabras clave: Antropoceno; Antropozoico; Escala del Tiempo Geológico; estratigrafía; forzamiento antrópico; huella humana.

\section{Cómo citar este artículo / Citation}

Rull, V. 2017. The "Anthropocene" uncovered. Collectanea Botanica 36: e008. doi: http://dx.doi.org/10.3989/collectbot.2017. v36.008

\section{Copyright}

(C) 2017 CSIC. Este es un artículo de acceso abierto distribuido bajo los términos de la licencia Creative Commons Attribution License (CC BY) Spain 3.0. 


\section{INTRODUCTION}

The use of the term "Anthropocene" is growing fast and spreading over a wide range of scientific and non-scientific disciplines. This term embodies not only the notion of the ongoing anthropogenic global change but also its human perception and the resulting socio-political and philosophical repercussions. As a consequence, the "Anthropocene" has become a successful term and concept to express the nature and characteristics of the human footprint on Earth. Although the term "Anthropocene" was born in a scientific environment, it is now intensively and extensively used in many other areas such as philosophy, sociology, communication, politics or law, just to cite a few. From a scientific point of view, the term "Anthropocene" was proposed to designate the new geologic epoch in which we live, characterized by the global impact of human activities on the Earth System (Crutzen \& Stoermer, 2000; Crutzen, 2002). But in other disciplines, this term has adopted a variety of meanings. For example, in philosophy, the "Anthropocene" has been considered as an expression of modernity, an attack to the Earth System or a biological imperative, that is, something inevitable and inherent to the human existence. In a political context, this term has been contemplated as an assault to the human rights, a logical consequence of the global capitalism or the definitive decoupling between environmental health and human welfare (Autin, 2016).

Despite its frequent and widespread usage, the convenience or not of using the term "Anthropocene" is under vibrant debate (e.g. Edwards, 2015; Finney \& Edwards, 2015; Zalasiewicz et al., 2016a, 2017). Some use the term with quotation marks, as usual for informal geological names, others without them as if the term were already official, and others deny its usage at all (Klein, 2015), which might create confusion among non-specialists and the general public. Some mass media also add noise by using headlines and spreading news that often distort the facts. Examples are: Welcome to the Anthropocene (The Economist, May 26th 2011), Anthropocene: new dates proposed for the 'Age of Man' (BBC, March 11th 2015) or The Anthropocene epoch: scientists declare dawn of human-influenced age (The Guardian, August 29th 2016). The issue is not only a matter of using or not quotation marks for the "Anthropocene" while waiting for its eventual approval as a formal term. The scientific validity of both the name and the concept of the "Anthropocene" is currently under discussion and the final outcome, for which we should still wait several years, is totally uncertain.

This essay aims to help clarifying the topic by summarizing the main points of view existing to date and the current status of the term in a scientific context. The analysis highlights the following points that are often ignored or go unnoticed (Rull, in press): (1) the "Anthropocene" is not a recent invention, it was already proposed about one century and a half ago, but this has been neglected; (2) its frequent and extended usage may lead non-specialists to the misconception that the term is already a formal official unit of Geologic Time Scale (GTS) but, in fact, it is not even a proposal of it; and (3) as currently defined, the "Anthropocene" is a bet on the future and, as such, its meaning and eventual formalization are dependent on the future development of human affairs, which are largely unpredictable. This paper is intended for a wide audience, with or without earth-science background and familiarized or not with the topic of the "Anthropocene", but interested in knowing more on what lies behind this name, which has transcended the scientific arena and seems to be gaining a place in everyday language.

\section{THE "ANTHROPOCENE" IS AN OLD CONCEPT}

Some authors defend that the concept of the "Anthropocene" has no precursors (Hamilton \& Grinevald, 2015) and give all credit to Crutzen \& Stoermer (2000), who coined the term at the beginning of this century. But the idea of a new unit of the GTS defined by the global human impact on Earth and its imprint in the geological record was already advanced at least a century and a half ago. Since those times, a number of other similar proposals emerged. A brief account is provided here with emphasis on the "Antropozoic" era, which is the most comprehensive, accurate and geologically sound precursor of the "Anthropocene".

\section{The "Antropozoic" era}

Antonio Stoppani (1873; Fig. 1) proposed that the influence of humans on Earth and the resulting 


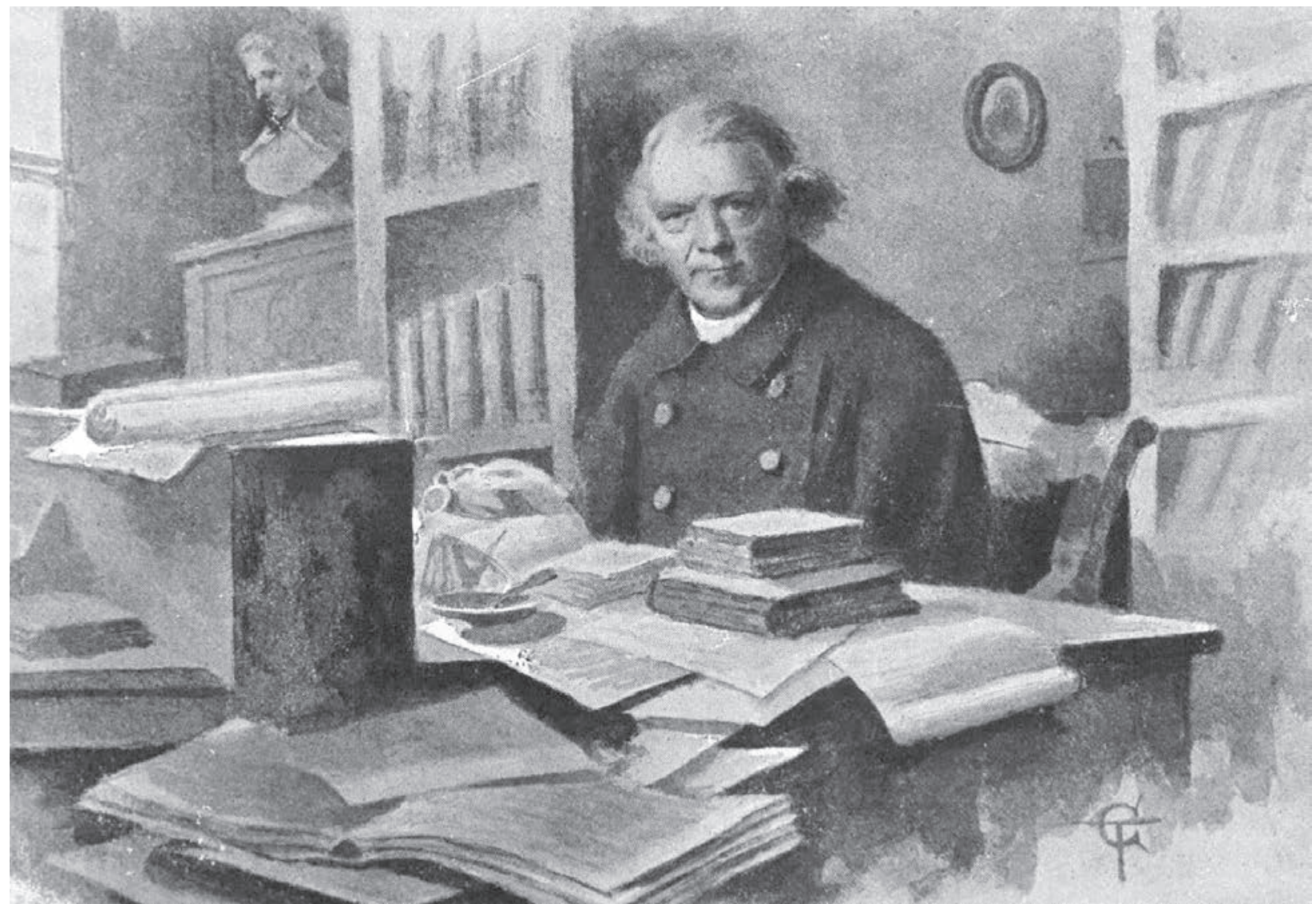

Figure 1. Antonio Stoppani (1824-1891) in his studio. Unknown author, modified from https://en.wikipedia.org/wiki/Antonio_Stoppani.

physical, biological and geological imprint was great enough to deserve the definition of a new era, which he called "Anthropozoic" (in geology, "-zoic" is the corresponding suffix for an era, whereas "-cene" is the specific suffix for an epoch). Stoppani not only defined the "Anthropozoic" but also pointed out that the rocks formed during human existence contained the physical evidence needed to define this new era in geological terms. Geological time units should be defined on the basis of characteristic rock features, it is not possible to describe and name a new geological unit without the corresponding tangible evidence contained in rocks, which form the geological clock. Geological time cannot be measured without such clock, whose time units are rock layers, called strata. Stratigraphy is the geological branch that studies the nature of these strata and their chronological succession. Stoppani described accurately how mankind have transformed the Earth's sedimentary processes and how what he called "human relicts" (tools, weapons, buildings and any products of art and industry) have been accumulating in recent rocks following the laws of stratigraphy. He also identified the potentially better suited rocks to be used to define the "Anthropozoic" and suggested, among others, recent slumps lacustrine and marine sediments, alluvial plains, deltas, marshes, peat bogs, caves, glacial moraines or recent volcanic rocks. Stoppani also tried to identify a potential starting time for the new era. According to him, the onset of the "Anthropozoic" era should be placed at the beginning of the Stone Age, characterized by the first appearances of carved stone. However, Stoppani realized that these human relicts appeared at different times on the different regions of the planet and it would be difficult to find an initial date of global value. Despite being a novel and very well elaborated idea with sound stratigraphic grounds, the proposal of the "Anthropozoic" era was lost in the night of time. 


\section{Other similar terms and concepts}

The "Anthropozoic" is not the only term coined to define a new geological unit characterized by the human impact on Earth and its stratigraphic imprint. Other terms have appeared through history as for example the "Psychozoic", or the "reign of mind", proposed by Joseph Le Conte (1883). According to this author, the new era began in the $\mathrm{Ne}$ olithic, characterized by the development of tools of polished stone and the worldwide expansion of the agriculture, but Le Conte did not make emphasis on the global influence of human activities on Earth or in the geological record. In 1922, Alexei Pavlov coined the term "Anthropogene" to refer to the period ("-gene" is the formal suffix for a geological period) of existence of the genus Homo (Gerasimov, 1979), unlike Stoppani and Le Conte, who considered their respective eras as defined by our species, Homo sapiens. Defined in this way, the "Anthropogene" would be more or less equivalent to the present Quaternary period, characterized by the occurrence of recurrent global glaciations. Shortly after, in the 1920s, Pierre Teilhard de Chardin created the term "noosphere" or the "sphere of mind" as the thinking layer of Earth, by analogy with the atmosphere (the aerial layer) or the biosphere (the living layer). At the beginning, the noosphere was a purely metaphysical concept (Teilhard de Chardin, 1955) but a decade later, Vladimir Vernadsky, the father of the biogeochemistry, developed the idea and emphasized that the noosphere could be considered the result of the human transformation of the biosphere boosted by the industrialization, which revolutionized the productive capacity of humans and transformed humankind into a new geological force capable of affecting the Earth System as a whole (Vernadsky, 1997). The noosphere has remained in history as the third stage in the evolution of Earth, after the geosphere (the inanimate layer) and the biosphere, rather than as a proposal for a new geological era.

The term "atomic age" (also known as "atomic era") was introduced by journalist William Lawrence in 1946, just after the Second World War, to define the new state of the Earth after the first nuclear explosions, which produced changes in the composition of the atmosphere with potentially significant biological and sociological consequences. The "atomic age" was not intended as a new unit of the GTS, it was considered only a new historical phase. More recently, George Ter-Stepanian (1988) considered that the current technological development of humankind was significant enough to define a new geological period, following the Quaternary, which he called "Technogene" or "Quinary". Few years later, Thomas Berry (1992) proposed that the increasing disruptions in the functioning of Earth System caused by the human misuse of technology will end at some point and will be followed by a new era, the "Ecozoic", characterized by a new state in which humans and Earth will live in harmony. The last term proposed before the "Anthropocene", and perhaps its more evident terminological precursoralthough it should be noted that some English translations from Russian used "Anthropocene" instead of "Anthropogene" for the already mentioned Pavlov's period-was the "Anthrocene", introduced by journalist Andrew Revkin (1992).

\section{The only survivor}

All these names and concepts, and others (Rull, in press), emerged before the definition of the "Anthropocene". Therefore, the precursors of this term and the concept it involves are evident, numerous and well documented, and cannot be ignored. Neglecting this background does not make sense, as most of this literature, including digital reproductions the original books of Stoppani or Le Conte, among others, are freely available on Internet. By reading these books it is easy to realize the inaccuracy of some statements as, for example, that of Zalasiewicz et al. (2017) who contend that the supposed "Anthropocene" precursors ". . . do not explicitly address the stratigraphic record". The Stoppani's Corso di Geologia (three volumes) can be read and downloaded in some websites (e.g. https://catalog.hathitrust.org/Record/001518767). The book is in Italian but Turpin \& Federighi (2012) provide an English translation of some excerpts relevant to the definition of the "Anthropozoic" era. The second volume is dedicated to stratigraphic geology and the "Anthropozoic" is defined, described and characterized in chapters 31 to 33 (121 pages). Stoppani analyzes in great detail the stratigraphic features of the "Anthropozoic" and subdivides this new "era" into its corresponding stratigraphic units, which are carefully characterized by their respective sedimentary rocks and stratigraphic markers including not only 
human remains but also fossil faunas. There are other "Anthropocene" precursors with stratigraphic meaning, as for example the "Antropogene" or the "Technogene". But the truth is that all of them have been neglected and the "Anthropocene" is the only currently under scrutiny as a potential geologic unit.

\section{CURRENT GEOLOGICAL STATUS OF THE "ANTHROPOCENE"}

One of the more extended misconceptions about the "Anthropocene" is its current status as a formal epoch of the GTS. Many people, including many scientists, believe that the "Anthropocene" is already an official geological epoch and, as such, the term can be freely used without quotation marks and capitalized. Noteworthy, there are three scientific journals that use the name as if it were already a formal term, they are: The Anthropocene (Elsevier), The Anthropocene Review (SAGE Publications) and Elementa: the Science of Anthropocene (University of California Press). However, this belief is far from true, as we will see in this section.

\section{Modifying the Geological Time Scale}

The International Commission on Stratigraphy (ICS) is the section of the International Union of Geological Sciences (IUGS) responsible for the definition, characterization and classification of the global units of the International Chronostratigraphic Chart (ICC), which are the basis for the units of the GTS. Any proposal for incorporating or modifying a stratigraphic unit of the ICC and, therefore, of the GTS, must be submitted to the ICS for approval. The ICC is for geoscience the same that the Periodic Table of Elements for chemistry, and has been considered one of the great achievements of humanity (Monastersky, 2015). The rules and requirements that guide the formalization of new stratigraphic units are compiled in the International Stratigraphic Guide (Salvador, 1994; Murphy \& Salvador, 1999). The detailed procedures are available at the ICS website (http://www.stratigraphy. org) and are summarized at following.

The ICS is structured into a number of subcommissions responsible for the standardization of particular stratigraphic units (e.g. Precambrian, Silurian, Jurassic, Cretaceous, Quaternary, etc.).
Each subcommission can organize working groups, whose task is to carefully analyze a particular stratigraphic boundary, usually the lower boundary that defines a stratigraphic unit. Once the working group has a final proposal for the boundary under study, it is submitted to the corresponding subcommission for approval, which requires $60 \%$ or more of the votes. If approved, the proposal goes to the ICS Bureau, which is formed by the Executive Committee of the ICS plus the chairmans of all subcommissions. Again, if the proposal receives $60 \%$ or more votes, it is approved and submitted to the Executive Committee of the IUGS for ratification. If ratified, the boundary and the new stratigraphic unit it defines are considered to be formalized (Fig. 2).

To be acceptable, a stratigraphic boundary should be globally synchronous and based on observable and/or measurable rock properties. The boundary should be the reflection of a global event, although its manifestation in each particular rock body can be different. For example, the beginning of the Quaternary, characterized by the onset of recent worldwide glaciations, can be marked by changes in the magnetic properties of rock components, shifts in the isotopic composition of selected elements or the extinction of characteristic marine plankton species, among others, but all these markers are a consequence of an intense and global cooling occurred $\sim 2.6$ million years ago, which initiated the glaciations. Each stratigraphic unit is defined in a particular sequence of rock strata (the stratotype) from a precise geographical location (the type locality) but it should have equivalent representatives worldwide. The specific properties that differentiate a unit from another are called stratigraphic markers. The lower boundary of a unit is called the Global Stratotype Section and Point (GSSP) and is indicated in the type locality by a physical mark, called "golden spike". The main task of each working group is to define the stratotype, the type locality and the GSSP for the stratigraphic unit they deal with, in order to submit a proposal to the corresponding subcommission and start the protocol for an eventual approval and ratification.

In the case of the "Anthropocene", the working group in charge is the Anthropocene Working Group (AWG) (https://quaternary.stratigraphy.org/ workinggroups/anthropocene/), belonging to the Subcommission of Quaternary Stratigraphy (SQS). The AWG was created in 2009 and is formed by 39 


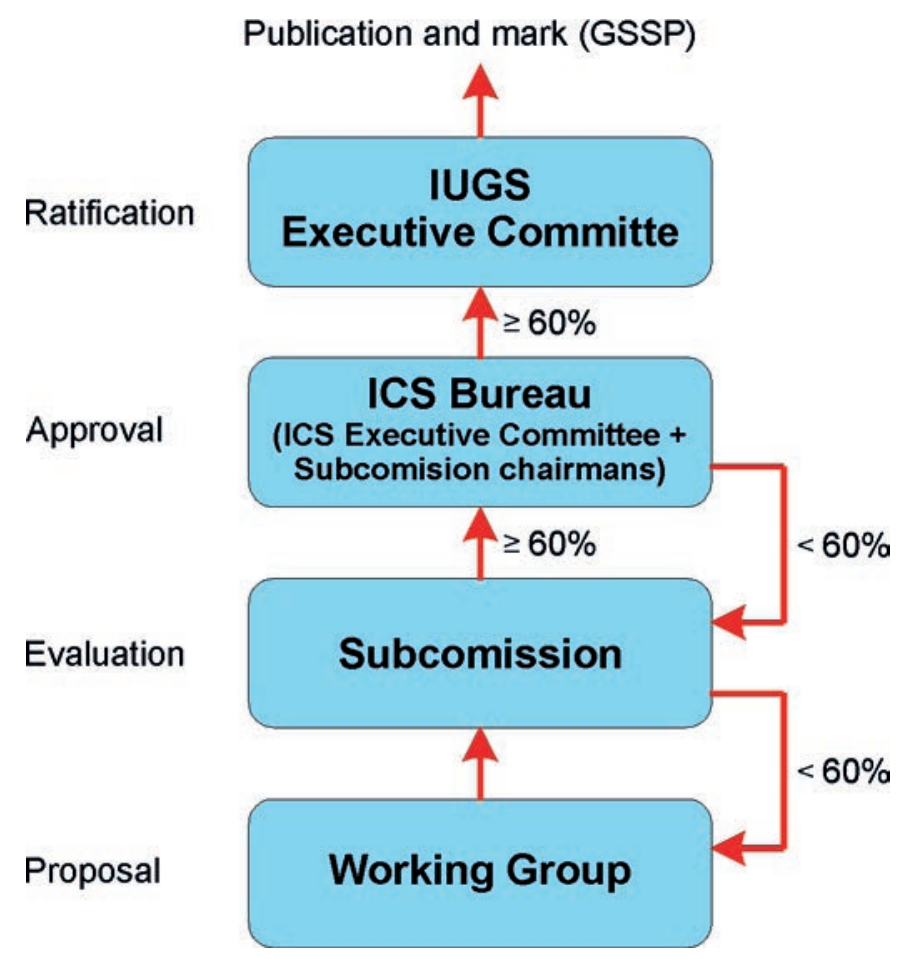

Figure 2. Flow chart of the approval and ratification procedure of new stratigraphic units, according to the rules of the ICS. Modified from Rull (in press). members, including several of the more enthusiastic defenders of the "Anthropocene" as a new epoch of the GTS, who have been very active promoting such initiative in the scientific literature (e.g. Steffen et al., 2011; Zalasiewicz et al., 2011a, b, 2015, 2016b, 2017; Waters et al., 2014, 2016) and also in public media. But the "Anthropocene" is still in a very early stage of the ICS protocol for approval and ratification. In fact, it is not even a proposal yet. After seven years of discussions, the members have not yet defined a stratotype, a type locality and a GSSP for the "Anthropocene". Therefore, the "Anthropocene" proposal does not yet exist.

\section{Many possible "anthropocenes"}

Characterizing the human impact on Earth by a single worldwide event and its corresponding stratigraphic imprint of global validity in the geological record is not easy. In the original definition, the onset of the "Anthropocene" was placed in the second half of the 18th century, at the beginning of the industrial revolution, characterized by an increase in the atmospheric $\mathrm{CO}_{2}$ concentration without parallel in human history (Crutzen \& Stoermer, 2000). The industrialization represented the end of the agriculture as the dominant economic activity, which determined a deep change in human lifestyle and generat- ed a new economic order. Until that time, the main energy sources were the movement of water and air and the biological activity of primary producers, all of them derived from solar energy. With the discovery of fossil fuels, the available energy increased by 40 times between 1800 and 2000, which derived in a 50-fold production increment and an increase of total population from one to six billion people. One of the main products of the fossil fuel combustion is $\mathrm{CO}_{2}$, which atmospheric concentration increased from about 280 to $380 \mathrm{ppm}$ during the same period and, given its significant greenhouse effect, contributed to the ongoing global warming (Waters et al., 2014; Lewis \& Maslin, 2015).

The more dramatic shift occurred after the Second World War ( 1950), during the phase known as the "great acceleration", when all the indicators of human activity experienced an amazing quickening (Fig. 3). Human population increased by 3 billion in only 50 years and the economic production multiplied by 15 during the same period. The number of motor vehicles raised from 40 to 700 million, the petroleum consumption increased 3.5 times and the concentration of greenhouse gases $\left(\mathrm{CO}_{2}\right.$, methane, fluorocarbons...) experienced a dramatic increment. The industrialization also caused the concentration of human population in big cities and the humanization of nearly the half 


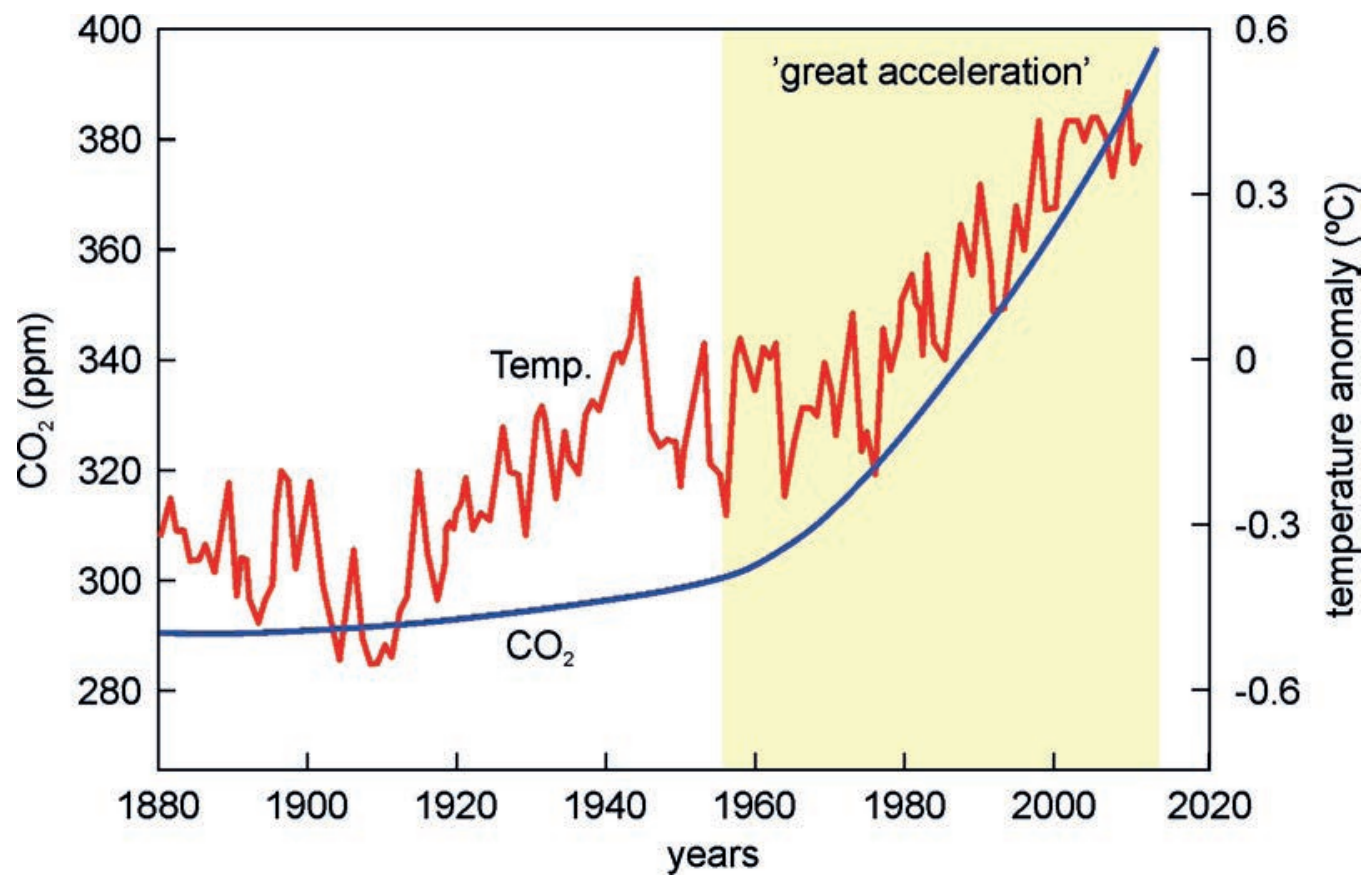

Figure 3. Changes in global temperature and atmospheric $\mathrm{CO}_{2}$ concentration during the last century. $\mathrm{CO}_{2}$ concentration is expressed as parts per million (ppm) and temperature as the anomaly with respect with the 1961-1990 average. Modified from Lewis \& Maslin (2015).

of the terrestrial surface (Ellis et al., 2010, 2015). Biodiversity depletion also accelerated and some refer to the "sixth mass extinction" (Dirzo et al., 2014) by analogy with former mass extinctions observed in the geological record, of which the dinosaur extinction, occurred 66 million years ago, was the fifth. Atmospheric radioactivity also increased due to nuclear detonations, which started in 1945 and were not abolished until 1996.

The geological imprint of the industrialization and the "great acceleration" are numerous and varied, especially in lake and sea sediments, as well as in polar ice. Potential stratigraphic markers for the "Anthropocene", as defined by Crutzen \& Stoermer (2000), are the particles called "fly ashes", released to the atmosphere by fossil fuel combustion, which ultimately accumulated in sediments and ice sheets. The accumulation of radioactive elements as for example isotopes of carbon $\left({ }^{14} \mathrm{C}\right)$, plutonium $\left({ }^{239+249} \mathrm{Pu}\right)$, lead $\left({ }^{210} \mathrm{P}\right)$ or cesium $\left({ }^{137} \mathrm{Cs}\right)$, among others, is also a differential signature to define the "Anthropocene" onset. Other possible markers are shifts in the composition of fossil assemblages in lake sediments as a result of drastic changes in the aquatic communities due to the eutrophication of these water bodies by fertilization with nutrients released by human activities, a phenomenon of worldwide extent, especially in the northern temperate countries. Another potential stratigraphic marker is plastic and other synthetic materials, nonexistent before the industrialization, but present in the more recent sediments (Zalasiewicz et al., 2011a, b; Waters et al., 2014, 2016).

Other scholars argue that the "Anthropocene" began much earlier, with the worldwide expansion of the agriculture occurred between 8000 and 6000 years before present, which is known as the "Neolithic revolution" (Ruddiman, 2003, 2013). This is called the "early Anthropocene" hypothesis. The main consequences of the global development of agriculture were the replacement of original vegetation, which favors local extinction and, as a consequence, biodiversity reduction and the disruption of global biogeochemical cycles, which affects the atmospheric composition. In humans, the "Neolithic revolution" caused a drastic change from nomadic hunter-gatherer to more sedentary societies dedicated to the care of domestic plants and animals, which determined the establishment of more permanent settlements and leaded to the development of cities. Ecosystems were profoundly affected, mainly forests, which began to be cut and burnt and replaced by crop fields. In this case, the stratigraphic markers could be the occurrence, in the sedimentary rocks formed in those dates, of pollen 
of cultivated plants, fossils of domestic ruminants or human tools related with these activities. Other proposed markers are $\mathrm{CO}_{2}$ and methane concentrations, which experienced an increase 8000 and 5000 years ago, respectively, as documented in polar ice sheets (Fig. 4). The $\mathrm{CO}_{2}$ increase has been interpreted as the consequence of forest burning, which released significant amounts of $\mathrm{CO}_{2}$ to the atmosphere. The increase of methane has been considered to be the result of the development of rice cultivation, which requires permanently flooded terrains thus favoring anoxic conditions and increasing methane production (Ruddiman, 2013, 2015).

Others propose different dates for the "Anthropocene" onset, as for example the worldwide extinction of large mammals occurred between 50,000 and 10,000 years before present (BP). The causes for the global disappearance of about the half of large mammal species (over $40 \mathrm{~kg}$ of body weight in adult stage) from most continents, except Africa, are still debated. Some believe that megamammals did not resist the incoming of warmer climates after the last glaciation, whereas others defend that massive human hunting was the main cause and a third group considers that both climatic and anthropogenic drivers would have been involved (Barnosky et al., 2004; Lorenzen et al., 2011; Barnosky, 2014).
Whatever the cause, megafaunal extinction would have resulted in a global biological reorganization by changing the composition and the functioning of ecosystems from most continents. For those who defend the anthropogenic explanation, the stratigraphic markers for this "Anthropocene" would be the joint accumulations of mammal fossils and hunting tools observed in sedimentary rocks.

Another proposal is to place the onset of the "Anthropocene" in the discovery of America (1492) or slightly later $(\sim 1600)$, which has been considered the first globalization event, known as the "Columbian interchange", resulting in a worldwide biological revolution leading to biotic mixing and reorganization of the biosphere (Crosby, 2003; Mann, 2011). Another consequence was the significant reduction of the American population-from about 50-60 million people in 1492 to six million in 1650 - as a consequence of wars, slave trading, starvation and the introduction of alien epidemic diseases. According to Lewis \& Maslin (2015), this would have been reduced agriculture and the associated deforestation habits thus favoring the recovery of more than 50 million hectares of forests and savannas. The main stratigraphic markers of this event would be fossils of American plants in European rocks or fossils from plants native to Asia in American rocks, from 1600

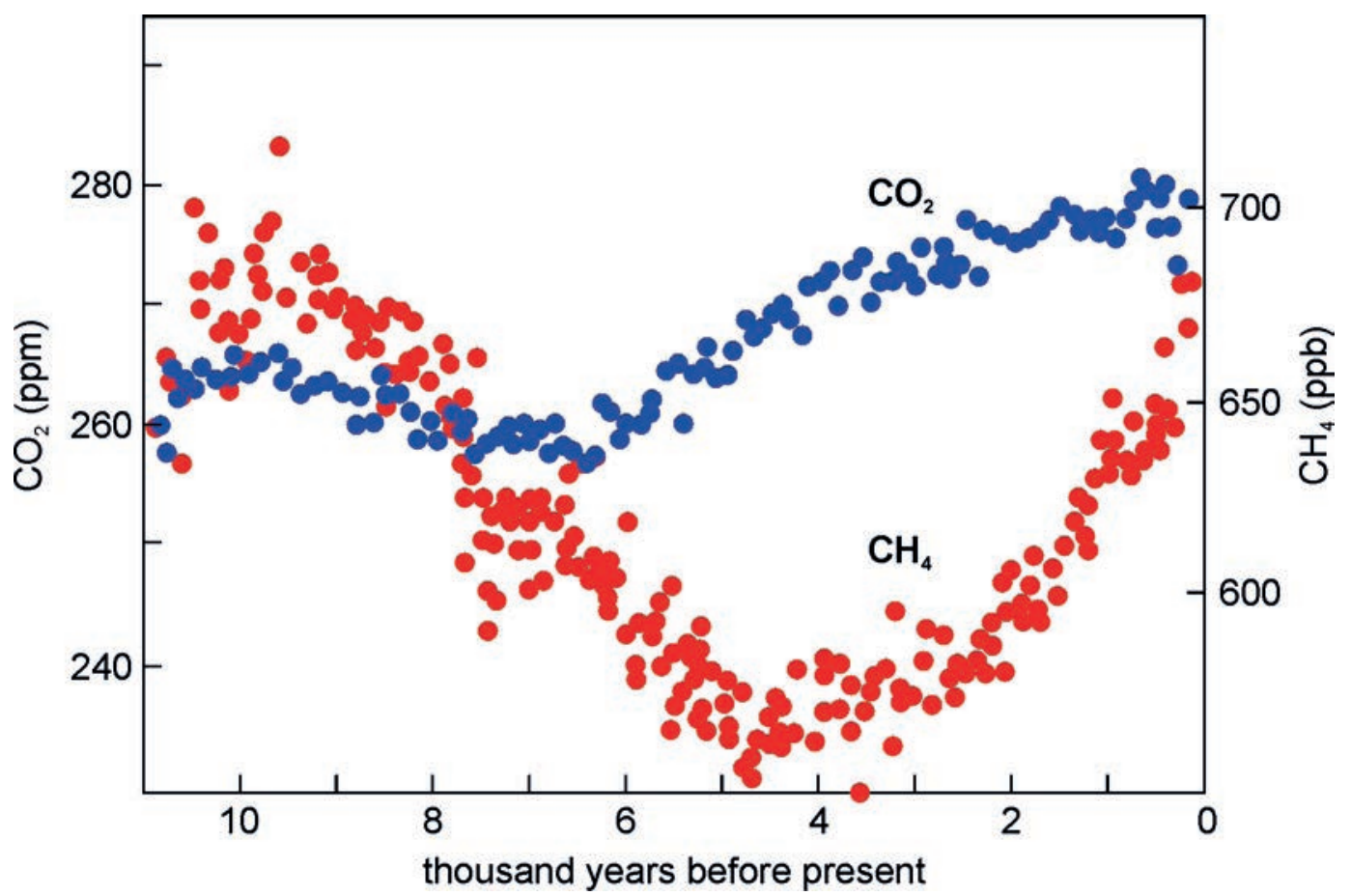

Figure 4. Changes in the atmospheric concentration of carbon dioxide $\left(\mathrm{CO}_{2}\right)$ and methane $\left(\mathrm{CH}_{4}\right)$ during the Holocene (ppm: parts per million; ppb: parts per billion). Modified from Ruddiman (2013). 
onwards. Another marker would be the reduction of atmospheric $\mathrm{CO}_{2}$ observed in polar ice sheets between 1570 and 1620 , possibly as a consequence of an increase of photosynthesis owing to forest/savanna recovery (Lewis \& Maslin, 2015).

\section{The current status}

All the above possibilities and others were analyzed by the AWG and the final decision was taken by voting, during the 35th International Geological Congress held at Cape Town in August 2016. The AWG agreed in locating the onset of the "Anthropocene" in 1945 and suggested that the better stratigraphic marker could be the plutonium increase generated by the atomic explosions. The detailed report of the AWG Cape Town meeting is reproduced in the Appendix. The coincidence of this "Anthropocene" with Lawrence's "atomic age" is evident, in both timing and concept. There is also a good chronological match with the "great acceleration". Now, the AWG is looking for the best stratotype and GSSP to fit with the ICS rules, a task that, according to their own words, is expected to be accomplished in 2-3 years. Therefore, we should still wait at least a couple of years for the "Anthropocene" proposal to be ready and initiate its way through the complex ICSIUGS approval and ratification protocol (Fig. 2).

\section{THE SCIENTIFIC DEBATE}

The AWG procedures and the resulting outcomes have received scientific criticism, mostly from stratigraphers, especially some members of the ICS and IUGS executive committees (Finney, 2014; Gibbard \& Walker, 2014; Edwards, 2015; Finney \& Edwards, 2015; Walker et al., 2015). This could be viewed as a warning to the AWG about the inadequacy of the current definition of the "Anthropocene" according to the international stratigraphic rules. This call to attention suggests that, in its current status, the proposal could not be approved by the ICS and ratified by the IUGS. The main conflicting points are summarized here.

\section{Scientific criticism}

Some critics argue that the procedure followed to progress in the elaboration of the "Anthropocene" proposal is incorrect. According to the ICS rules, the definition of a new stratigraphic unit should come from a stratigraphic need, that is, from the existence of a rock body that should be defined, named, characterized and dated, in order to be included in the ICC. On the contrary, the AWG is trying to force the definition of a new stratigraphic unit on the basis of pre-defined historical and chronological concepts. Defined in this way, the "Anthropocene" stratotype, its stratigraphic markers and its GSSP are not the primary evidence for the new stratigraphic unit - as required by the stratigraphic rules - and are subjected to changes according to the chronological criterion adopted by the AWG. Thus, the "Anthropocene" is not an evidence-based concept and is therefore beyond the scientific scope.

Another drawback is that the decision of the AWG to place the onset of the "Anthropocene" in 1945 significantly reduces the probability of finding the desired stratotype, which should be sought in the slim and fragile sedimentary layer deposited during the last $\sim 70$ years. This turns the idea of the "Anthropocene" into a prospect for the future, in the hope that these thin and unconsolidated layers will remain and keep growing until they can unequivocally be recognized and traced across the Earth by future geologists. According to the critics, such concept cannot be a stratigraphic target of study as stratigraphy is concerned with the past, rather than the future. Those who criticize the AWG in this way claim that other options for the "Anthropocene" onset - for example, the "early Anthropocene" proposal (Ruddiman, 2013) would have provided more room for finding a suitable stratotype in the already existing rocks. In addition, Finney \& Edwards (2015) note that this definition of the "Anthropocene" coincides with the "atomic age" as defined by Lawrence in 1946 and, therefore, the term "atomic age" has priority, according to the rules of the International Stratigraphic Guide (Salvador, 1994; Murphy \& Salvador, 1999).

Choosing 1945 as a starting date has also created internal criticism inside the AWG. This date received 28 votes of the 35 AWG members who attended the deliberations at Cape Town (Appendix). Four AWG members voted that the onset of the "Anthropocene" should not be necessarily synchronous worldwide as the manifestations of human presence and impact occur at different 
times, at different regions of Earth (Edgeworth et al., 2015; Ellis et al., 2016). But this is against the stratigraphic rules that require global synchroneity to define a stratigraphic unit and its corresponding GSSP. However, it expresses the real asynchronous nature of the anthropogenic imprint on the stratigraphic record, which is why some believe that the "Anthropocene" cannot be formalized at all.

It has also been asked why Crutzen, Stoermer and the AWG implicitly assumed, since the beginning, that the stratigraphic unit representing the global human impact on the Earth System should be an epoch, as is implicit in the suffix "-cene", rather than an era-as for example the Stoppani's "Anthropozoic"-or a period, such as the Pavlov's "Anthropogene" (Rull, 2016b). There is no a clear statement in this sense. Sometimes, the AWG members mention that the "Anthropocene" could have the rank of an era in the planet's history (e.g. Williams et al., 2015) but they never shift from "Anthropocene" to "Anthropozoic" to refer to it.

Recently, AWG members responded to most of the above critiques, and others, maintaining their core ideas almost intact (Zalasiewicz et al., 2017). The only point in which they seem to be more cautious is in the initial date. Despite the 2016 Cape Town decision after massive voting, the AWG now declares that placing 1945 as the beginning of the "Anthropocene" was not a final decision, only a suggestion and ". . . a contribution to open discussion about where, and how, the boundary might be placed" (Zalasiewicz et al., 2017). With this novel assessment, it is no clear whether or not the AWG will maintain the 1945 boundary in their final proposal. But according to the AWG, the most important point is not the exact placement of the boundary but the idea that human modifications on Earth System, and their corresponding stratigraphic imprint will be irreversible, even if anthropogenic forcing ceases tomorrow.

Following this reasoning, Zalasiewicz et al. (2017) introduce an interesting comparison with the Cretaceous/Paleogene boundary, occurred 66 million years ago and characterized by the extinction of dinosaurs and a major biospheric revolution. Such revolution was the result of an almost instantaneous (in geological terms) phenomenon, a meteorite impact, which determined the formation of a centimeter-scale iridium anomaly in the sedimentary record, separating two different worlds.
A hypothetical observer could have been able to perceive, at a human time scale, a fundamental biospheric shift from the Cretaceous to the Paleogene in spite of their brevity. According to Zalasiewicz et al. (2017), this would be the case for the Holocene and the "Anthropocene" and, therefore, what they call the "brevity argument" of their critics-i.e. the paucity of the stratigraphic record of the last $\sim 70$ years - would lose strength.

\section{Environmental policy implications}

Some critics emphasize the existence of extra-scientific elements in the quest for the "Anthropocene" formalization. For example, Finney \& Edwards (2015) consider that the interest on the formalization of the "Anthropocene" as a new geological epoch obeys to political, rather than scientific reasons and that the ICS should not take scientific decisions under political pressure. This is not dismissed by the AWG members, many of whom believe that human impact on Earth should be formally recognized if only for the society and the government agencies to be aware of it. This has created another misconception in some sectors, as is the false impression that the critics of the "Anthropocene" are not concerned with climate change, overpopulation, overexploitation of natural resources, contamination or waste accumulation. In this atmosphere, an eventual rejection of the "Anthropocene" proposal by the ICS and the IUGS, even based strictly on scientific criteria, might be viewed as a manifestation of compliance with those who wildly exploit and devastate the planet. In other words, those who support the "Anthropocene" as a new geological epoch could be viewed by society as the "politically correct" scholars, whereas those who point out the current stratigraphic weaknesses for such formalization would appear as the unpopular "evil" fellows, not very different from those who negate the anthropogenic climate change. For example, Stanley Finney, member of the IUGS Executive Committeeto which the proposal will be eventually submitted for ratification (Fig. 2) — declared to feel "... like a lighthouse with a huge tsunami wave coming at it" in this situation (Voosen, 2016). Another geologist, who asked not to be named, believes that "There's a similarity [of "Anthropocene" defenders] to certain religious groups who are extremely keen on 
their religion - to the extent that they think everybody who doesn't practise their religion is some kind of barbarian" (Monastersky, 2015). Finney \& Edwards (2015) and other stratigraphers argue that both the society and the political class, in general, are aware enough of current and potentially future environmental problems and an eventual formalization of the "Anthropocene" would not contributed to improve the situation. The general impression is that the eventual formalization of the "Anthropocene" is a scientific issue and should be decoupled from environmental policy matters, as the roots of the current Earth's devastation is an economic and political, rather than academic, affair.

\section{Why not simply a historical epoch?}

It seems clear that we are changing the structure and the functioning of the Earth System in a way that is likely inaugurating a new cultural phase of humanity and its relationships with the planet. If so, this new phase is worth to be named using a specific term, as it occurs with other historical periods. But defining a new geological epoch, as the AWG pursues, is a totally different venture as it requires to fitting with the stratigraphic rules and procedures explained above. Some have proposed the use of "Anthropocene" as a historical term without any geological meaning, only to emphasize the anthropogenic impact on Earth (Edwards, 2015). This is a very frequent choice that has fostered, in part, the spectacular expansion of the word across many knowledge areas. However, the termination "-cene" is reserved for the formal geological epochs of the Cenozoic era and, therefore, the term "Anthropocene" implicitly refers to a geologic epoch and is scientifically incorrect until eventually formalized. A historical name free from stratigraphic burden should not contain the suffixes "-cene", "-zoic" or "-gene". As a consequence, "Anthropocene" or "Anthropozoic" are not good choices as purely historical terms. Therefore, until the "Anthropocene" is eventually formalized, we should either use this term with brackets or choose another term without stratigraphic meaning. If, finally, the "Anthropocene" is not formalized, its use should be avoided, which is very unlikely to occur, given the popularity that this term has acquired in many scientific and non-scientific environments (Edwards, 2015).

\section{DOES THE "ANTHROPOCENE" HAVE A FUTURE?}

As a bet on the future, it seems reasonable to analyze the "Anthropocene" in light of the possible futures that awaits our species, an aspect that is rarely considered in this context. In their introduction of the term, Crutzen \& Stoermer (2000) considered that the incoming of the "Anthropocene" could only be avoided by a global catastrophe- - huge volcanic eruptions, a nuclear war, asteroid impacts, a glaciation or a socio-ecological collapse caused by our own stupidity - that eliminates or significantly reduces human population. This opens the debate about how long will we living on this planet and influencing its functioning.

\section{Are we eternal?}

We can only speculate about our immortality as a species but many people seem to take for granted, perhaps somewhat thoughtlessly, that our presence and influence on the Earth would be permanent, whatever this means. Such perception is behind many predictions about the future Earth but is obviously based on religious and philosophical considerations on the eternity of human condition. If we were eternal, then the "Anthropocene", or any other unit with the prefix "anthropo-" would be the last unit of the GTS (Rull, 2016a). If so, perhaps this unit is worth to be upgraded to a higher stratigraphic rank, as for example an era, the "Anthropozoic", as proposed by Stoppani almost a century and a half ago. But what if we are perishable as a species?

The evolutionary knowledge accumulated to date shows that there are no eternal species; all of them end up extinct and there is no scientific reason to believe that we should be different. However, our extinction must not necessarily be catastrophic. There are other ways to become extinct as a species but leaving an evolutionary legacy in the form of one or more descendant species (Rull, 2009). Phyletic extinction is the only that ends with both the original species and its genetic pool. Catastrophic extinction is a particular type of phyletic extinction. Other types of extinction are called pseudo-extinctions, as part of the genetic pool of the original species is preserved in one (hybridization and anagenesis) or more descendant species (cladogenesis) (Fig. 5). No matter the process and 


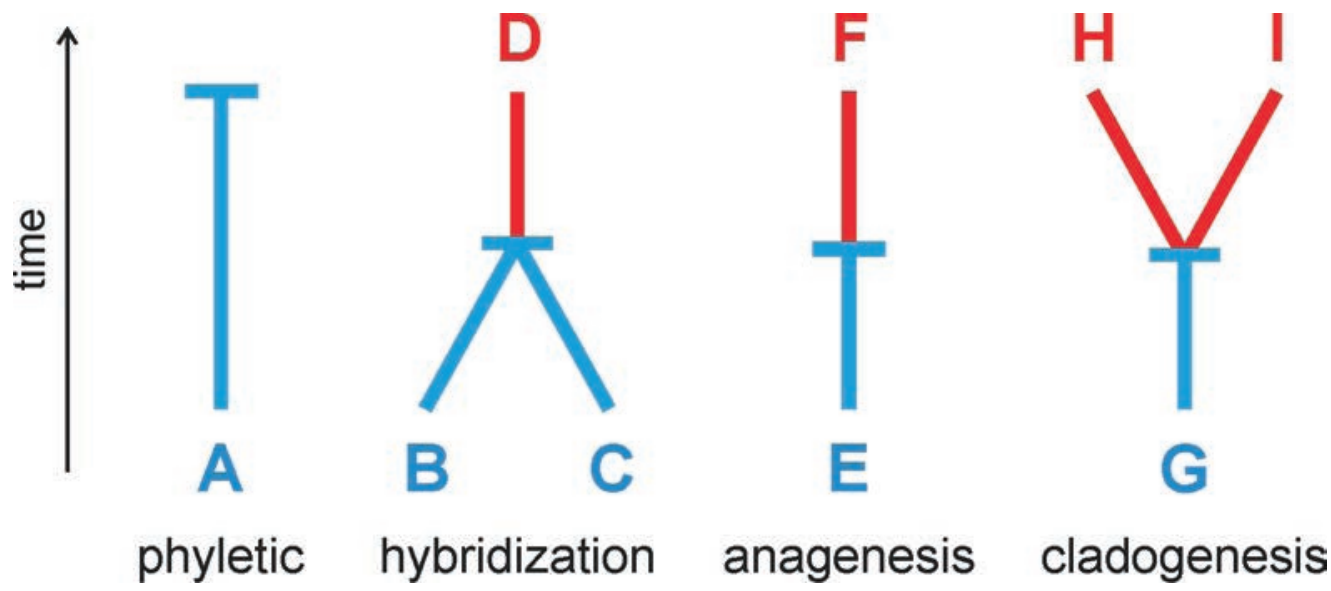

Figure 5. Four potential extinction types. Original species are depicted in blue and descendant species in red. Horizontal bars indicate the extinction of the original species. Modified from Rull (2009).

the consequences, our extinction as a species will mark the end of the "Anthropocene" or the "Anthropozoic" but the Earth and its biosphere will continue its sidereal pilgrimage. The biosphere has been rid of us during almost all its existence; it does not really need us and will persist after our disappearance, whatever the cause of our extinction. After this extinction, the issue of the "Anthropocene", the GTS and the whole stratigraphic framework, as human constructions, will not make sense anymore. The only hope for the GTS to keep alive is that our descendant species are still interested in stratigraphic affairs.

\section{Is our geological imprint irreversible?}

The AWG members believe that global changes characterizing the onset of the "Anthropocene" are irreversible and will permanently affect the stratigraphic record, no matter if our influence on the Earth System ceases or not (Williams et al., 2015; Zalasiewicz et al., 2017). For the time being, this is a matter of speculation. The question is whether human footprint will disappear at some point in time, with or without us on Earth. Crutzen \& Stoermer (2000) consider that a major catastrophe could have such effect. Such a catastrophe could totally eradicate our species or not. The first case has already been discussed. But besides our extinction as a species, how can our influence of the Earth System and the corresponding stratigraphic imprint disappear or become negligible? The only possibilities seem to be a drastic reduction in our global population and/or a change in our lifestyle and our relationships with the planet. In this case, the "Anthropocene" would finish even with us on board and a new geologic epoch (assuming that the remaining societies still care about stratigraphy) will start. Science-fiction alternatives, as for example the emigration of our species, or a significant part of it, to another planet or the construction of an artificial heliosphere in the Solar System have also been proposed (Rull, 2009; Cathcart, 1983, 2011) but will not be discussed here.

Among the catastrophes mentioned by Crutzen \& Stoermer (2000) that can drastically reduce human population, the only predictable, to a certain degree, using the available scientific background, is the incoming of the next glaciation. Since the beginning of the Quaternary, 2.6 million years ago, the Earth has experienced more than 40 glaciations consisting of an expansion of the polar ice sheets accompanied by the growth and downward extension of mountain glaciers worldwide, caused by global intense coolings (Ehlers et al., 2011). Each glaciation has been followed by a warmer phase of ice and glacier retreat known as an interglacial. The glacial/interglacial alternation follows a periodic trend governed by astronomical cycles linked to the Earth's movements around the Sun. The more recent glaciations have occurred at a 100,000-years period and the length of an interglacial ranged between 10,000 and 30,000 years. The maximum of the last glaciation occurred some 20,000 years ago and affected a large part of Europe and North America, which were under several kilometers depth ice sheets. At those times, most of Europe was covered by tundra and cold steppes, the forests that cover today most of the continent were "refugiated" in 
patches on the southern peninsulas (Iberia, Italy and Greece). Today's Mediterranean vegetation was still lacking (Elenga et al., 2000; Tarasov et al., 2000) (Fig. 6). At present, we are in the Holocene interglacial that began 11,700 years ago.

During the last glaciation, Europe and America were scarcely populated but a similar event today would radically reduce the population and create adverse environmental conditions for economic progress, especially in the more industrialized countries, which could cause a cultural collapse. Therefore, it seems opportune to ask when will the next glaciation begin. Models based on the observed Quaternary cyclicity estimate that the next glaciation could start in 1500 to 10,000 years and minimum temperatures would be reached by 60,000 years from now (Tzedakis et al., 2012). Therefore, if glacial cycles follow the same trends of the last $\sim 2.6$ million years under the same mechanisms of astronomical forcing, it is possible that current human influence on Earth System experiences a drastic decline in the next 60,000 years. In this case, the "Anthropocene" would have been a phase of some ten thousand years duration within the current Holocene interglacial, and the definition of a new geological epoch would not be necessary (Rull, 2013a). In other words, the "Anthropocene" would make sense only if current glacial-interglacial recurrence is disrupted. This could be due to an unlikely change in the physical dynamics of the Solar System or, more likely, to the eventual dominance of anthropogenic over astronomical forcing on Earth's climate for thousands or millions of years from now.

Some predictive model outputs suggest that current global warming will not stop and the next glaciation could be postponed indefinitely (Haqq-Misra, 2014; Herrero et al., 2014). In that case, physical evidence for the "Anthropocene" might keep accumulating for the benefit of future geologists, who would be able to properly define this epoch on a sound geological basis. In the absence of an external cataclysm, the only option to avoid a socio-ecological collapse seems to be a radical shift in the humanEarth relationships, which is a human responsibility. But even if we relax our pressure, the anthropogenic climate shift will persist for some time. Current models estimate that an eventual total cessation of greenhouse gas emissions will not stop the global warming, which would persist for decades or centuries until an eventual stabilization (Matthews \& Caldeira, 2008).

A hypothetical return to pre-industrial conditions is unpredictable but if it takes a similar time

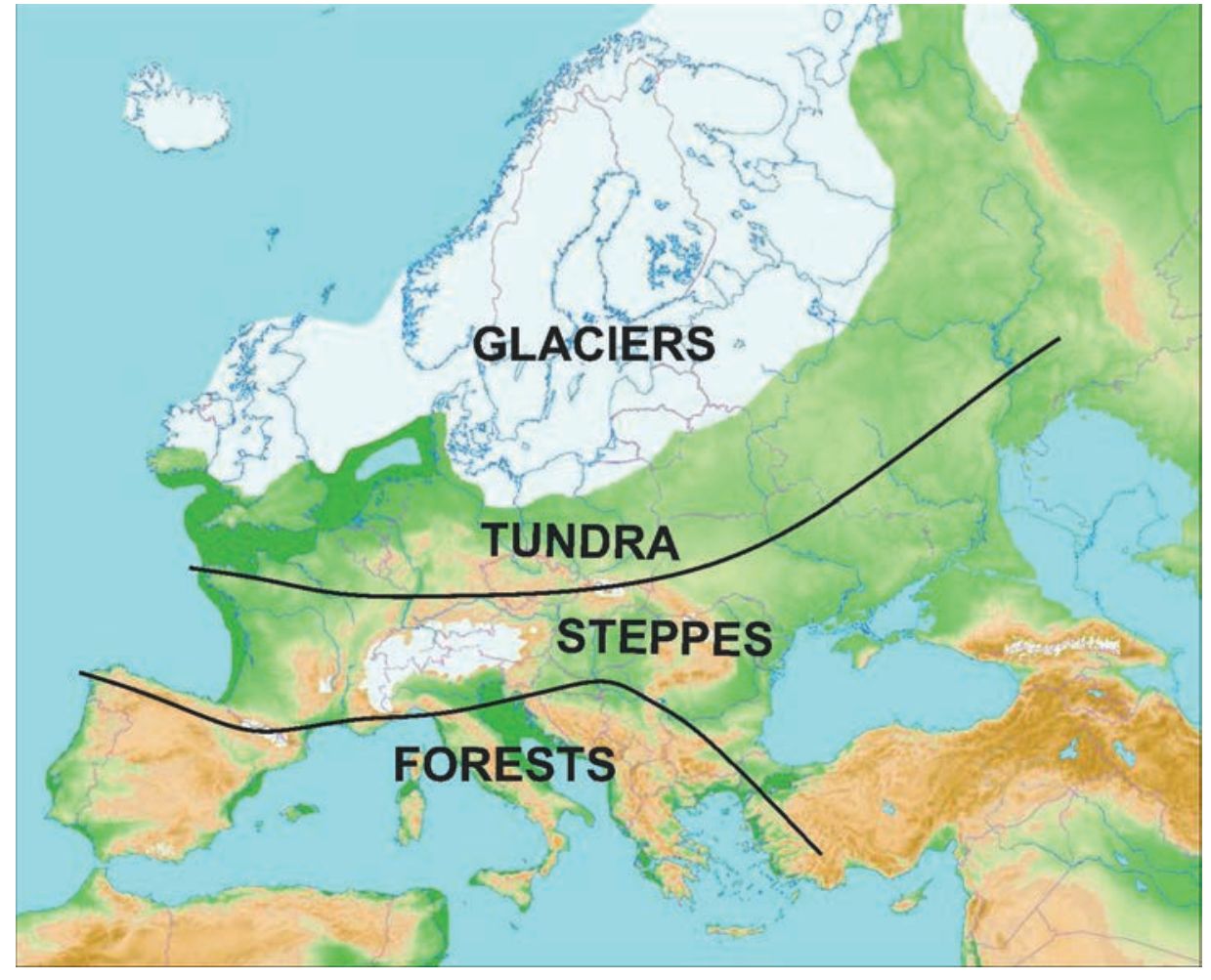

Figure 6. General aspect of Europe during the Last Glacial Maximum. Modified from (Rull, in press). 
lapse to be effective, the definition of a new geologic epoch like the "Anthropocene" or a new era like the "Anthropozoic" could be unnecessary. An eventual change in the way we impact the Earth System could be the result of either a change of mindset leading to a redefinition of our lifestyle or a cultural evolution to a human condition more integrated in the global ecological functioning and interested in its continuity. The first seems very unlikely in the current political and economic scenario (Rosen, 2015), whereas the second is still a matter of speculation without analogs in the evolutionary record. In addition, a hypothetical evolutionary trend towards a superior state of telluric consciousness could be viewed as a teleological expectation based on the desire of a better communion between humans and nature. But the available knowledge does not support this view, as evolution is not directional and finalist but intrinsically contingent and largely unpredictable (Rull, 2013b).

Summarizing, for the "Anthropocene" to become a reality, current levels of anthropogenic forcing should be maintained and the resulting impact on Earth system should overcome astronomical forcing so that the glacial-interglacial cyclicity is interrupted. If predictions about the next glaciation are correct, we should still wait one or more millennia (40 or more generations) for an answer. If a natural or anthropogenic global catastrophe annihilates humankind, the problem disappears with us. If we evolve into other species, the answer will depend on their eventual interest on geology and geological time. In the present state of knowledge, it is not possible to know whether the "Anthropocene" will be a new geological epoch - probably the last stratigraphic unit of the GTS - or an unnecessary term and concept. In such conditions, some ask what is the rush to formalize the "Anthropocene"?

\section{ACKNOWLEDGMENTS}

The author acknowledges the organizers of the cycle of public lectures on the "Anthropocene" held at the CSIC Delegation in Barcelona for their invitation to give the inaugural lecture, which was the origin of the present paper. My colleagues Santiago Giralt, Alberto Sáez and Jordi Cortès provided information, comments and insights that contributed to make my arguments more sound and clear. The comments and suggestions of two reviewers on the original manuscript are also acknowledged.

\section{REFERENCES}

Autin, W. J. 2016. Multiple dichotomies of the Anthropocene. The Anthropocene Review 3: 218-230. http://dx.doi. org/10.1177/2053019616646133

Barnosky, A. D. 2014. Palaeontological evidence for defining the Anthropocene. In: Waters, C. N., Zalasiewicz, J. A., Williams, M., Ellis, M. \& Snelling, A. M. (Eds.), A stratigraphical basis for the Anthropocene (Geological Society Special Publication, 395). The Geological Society of London, London: 149-165. https://doi.org/10.1144/SP395.6

Barnosky, A. D., Koch, P. L., Feranec, R. S., Wing, S. L. \& Shabel, A. B. 2004. Assessing the causes of Late Pleistocene extinctions on the continents. Science 306: 70-75. https://doi.org/10.1126/science. 1101476

Berry, T. 1992. A new era: healing the injuries we have inflicted on our planet. Health Progress 73: 60-63.

Cathcart, R. B. 1983. A megastructural end to geologic time. Journal of the British Interplanetary Society 36: 291-297.

Cathcart, R. B. 2011. Anthropic rock: a brief history. History of Geo-and Space Sciences 2: 57-74. https://doi.org/10.5194/ hgss-2-57-2011

Crosby, A. W. 2003. The Columbian exchange: Biological and cultural consequences of 1492. Praeger, Westport.

Crutzen, P. J. 2002. The geology of mankind. Nature 415: 23. https://doi.org/10.1038/415023a

Crutzen, P. J. \& Stoermer, E. F. 2000. The Anthropocene. Global Change Newsletter 41: 17-18.

Dirzo, R., Young, H. S., Galetti, M., Ceballos, G., Isaac, N. J. B. \& Collen, B. 2014. Defaunation in the Anthropocene. Science 345: 401-406. https://doi.org/10.1126/science. 1251817

Edgeworth, M., Richter, D. B., Waaters, C., Haff, P., Neal, C. \& Price, S. J. 2015. Diachronous beginnings of the Anthropocene: the lower bounding surface of anthropogenic deposits. The Anthropocene Review 2: 33-58. https://doi. org/10.1177/2053019614565394

Edwards, L. E. 2015. What is the Anthropocene? EOSEarth \& Space Science News 96(2): 6-7. https://doi. org/10.1029/2015EO040297

Ehlers, J., Gibbard, P. L. \& Hughes, P. D. (Eds.) 2011. Quaternary Glaciations - Extent and Chronology. Elsevier, Amsterdam.

Elenga, H., Peyron, O., Bonnefille, R. et al. 2000. Pollen-based biome reconstruction for souther Europe and Africa 18,000 yr BP. Journal of Biogeography 27: 621-634. https://doi. org/10.1046/j.1365-2699.2000.00430.x

Ellis, E. C. 2015. Ecology in an anthropogenic biosphere. Ecological Monographs 85: 287-331. https://doi. org/10.1890/14-2274.1

Ellis, E. C., Goldewijk, K. K., Siebert, S., Lightman, D. \& Ramankutty, N. 2010. Anthropogenic transformation of the biomes, 1700 to 2000. Global Ecology and Biogeography 19: 589-606. https://doi.org/10.1111/j.14668238.2010.00540.x

Ellis, E., Maslin, M., Boivin, N. \& Bauer, A. 2016. Involve social scientists in defining the Anthropocene. Nature 540: 192-193. https://doi.org/10.1038/540192a

Finney, S. C. 2014. The 'Anthropocene' as a ratified unit of the ICS International Stratigraphic Chart: fundamental issues that must be addressed by the Task Group. In: Waters, C. N., Zalasiewicz, J. A., Williams, M., Ellis, M. A. \& Snelling, A. M. (Eds.), A stratigraphical basis for the Anthropocene (Geological Society Special Publication, 395). The 
Geological Society of London, London: 23-28. https://doi. org $/ 10.1144 / \mathrm{sp} 395.9$

Finney, S. C. \& Edwards, L. E. 2015. The "Anthropocene" epoch: scientific decision or political statement? GSA Today 26: 4-10. https://doi.org/10.1130/GSATG270A.1

Gerasimov, I. 1979. Anthropogene and its major problem. Boreas 8: 23-30. https://doi.org/10.1111/j.1502-3885.1979.tb00428.x

Gibbard, P. L. \& Walker, M. J. C. 2014. The term 'Anthropocene' in the context of formal geological classification. In: Waters C. N., Zalasiewicz, J. A., Williams, M., Ellis, M. A. \& Snelling, A. M. (Eds.), A stratigraphical basis for the Anthropocene (Geological Society Special Publication, 395). The Geological Society of London, London: 29-37. https:// doi.org/10.1144/sp395.1

Hamilton, C. \& Grinevald, J. 2015. Was the Anthropocene anticipated? The Anthropocene Review 2: 59-72. https://doi. org/10.1177/2053019614567155

Haqq-Misra, J. 2014. Damping of glacial-interglacial cycles from anthropogenic forcing. Journal of Advances in Modeling Earth Systems 6: 950-955. https://doi. org/10.1002/2014MS000326

Herrero, C., García-Olivares, A. \& Pelegrí, J. L. 2014. Impact of the anthropogenic $\mathrm{CO}_{2}$ on the next climatic cycle. Climatic Change 122: 283-298. https://doi.org/10.1007/ s10584-013-1012-0

Klein, G. D. 2015. The ANTHROPOCENE: what is its geological utility? (Answer: It has none!) Episodes 38: 218.

Le Conte, J. 1883. Elements of geology. D. Appleton, New York.

Lewis, S. L. \& Maslin, M. A. 2015. Defining the Anthropocene. Nature 519: 171-180. https://doi.org/10.1038/nature14258

Lorenzen, E. D., Nogués-Bravo, D., Orlando, L. et al. 2011. Species-specific responses of Late Quaternary megafauna to climate and humans. Nature 479: 359-364. https://doi. org/10.1038/nature 10574

Mann, C. C. 2011. 1493: How Europe's discovery of the Americas revolutionized trade, ecology and life on Earth. Granta Books, London.

Matthews, H. D. \& Caldeira, K. 2008. Stabilizing climate requires near-zero emissions. Geophysical Research Letters 35: L04705. http://dx.doi.org/10.1029/2007GL032388

Monastersky, R. 2015. Anthropocene: the human age. Nature 519: 144-147. https://doi.org/10.1038/519144a

Murphy, M. A. \& Salvador, A. 1999. International Stratigraphic Guide - an abridged version. Episodes 22: 255-271.

Revkin, A. 1992. Global warming: Understanding the forecast. Abbeville Press, New York.

Rosen, A. M. 2015. The wrong solution at the right time. Politics \& Policy 43: 30-58. https://doi.org/10.1111/polp.12105

Ruddiman, W. F. 2003. The anthropogenic greenhouse gas era began thousands of years ago. Climatic Change 61: 261293. https://doi.org/10.1023/B:CLIM.0000004577.17928.fa

Ruddiman, W. F. 2013. The Anthropocene. Annual Review of Earth and Planetary Sciences 41: 45-68. https://doi. org/10.1146/annurev-earth-050212-123944

Ruddiman, W. F., Ellis, E. C., Kaplan, J. O. \& Fuller, D. Q. 2015. Defining the epoch in which we live. Is a formally designated Anthropocene a good idea? Science 348: 39-39. https://doi.org/10.1126/science.aaa7297

Rull, V. El 'Antropoceno'. Editorial CSIC-La Catarata, Madrid (in press).

Rull, V. 2009. Beyond us. Is a world without humans possible? EMBO Reports 10: 1191-1195. https://doi.org/10.1038/ embor.2009.225
Rull, V. 2013a. A futurist perspective on the Anthropocene. Holocene 23: 1198-1201. https://doi. org/10.1177/0959683613483628

Rull, V 2013b. Are we willing to build a better future? Trends in Ecology \& Evolution 28: 443-444. https://doi. org/10.1016/j.tree.2013.05.006

Rull, V. R. 2016a. The Anthropocene: a requiem for the Geologic Time Scale? Quaternary Geochronology 36: 76-77. https://doi.org/10.1016/j.quageo.2016.08.006

Rull, V. 2016b. The Humanized Earth System (HES). The Holocene 26: 1513-1515. https://doi. org/10.1177/0959683616640053

Salvador, A. 1994. International Stratigraphic Guide. A Guide to Stratigraphic Classification, Terminolog\& and Procedure (2nd ed.). International Union of Geological Sciences, Trondheim \& Geological Society of America, Boulder.

Steffen, W., Grinevald, J., Crutzen, P. \& McNeill, J. 2011. The Anthropocene: conceptual and historical perspectives. Philosophical Transactions of the Royal Society A 369: 842-867. https://doi.org/10.1098/rsta.2010.0327

Stoppani, A. 1873. Corso di Geologia (3 vols.). G. Bernardoni e G. Brigola Ed., Milano.

Tarasov, P. A., Volkova, V. S., Webb, T. et al. 2000. Last glacial maximum biomes reconstructed from pollen and plant macrofossil data from northern Eurasia. Journal of Biogeography 27: 609-620. https://doi.org/10.1046/j.13652699.2000.00429.x

Teilhard de Chardin, P. 1955. Le phénomène humain. Éd. du Seuil, Paris.

Ter-Stepanian, G. 1988. Beginning of the Technogene. Bulletin of the International Association of Engineering Geology 38: 133-142. https://doi.org/10.1007/BF02590457

Turpin, E. \& Federighi, V. 2012. A new element, a new force, a new input: Antonio Stoppani's Anthropozoic. In: Ellsworth, E. \& Kruse, J. (Eds.), Making the geologic now. Punctum Books, Brooklin: 34-41.

Tzedakis, P. C., Channell, J. E. T., Hodell, D. A., Kleiven, H. F. \& Skinner, L. C. 2012. Determining the natural length of the current interglacial. Nature Geoscience 5: 138-141. https://doi.org/10.1038/ngeo1358

Vernadsky, V. I. 1997. Scientific thought as a planetary phenomenon (translated by B. A. Starostin). Nongovernmental Ecological V.I. Vernadsky Foundation, Moscow.

Voosen, P. 2016. Atomic bombs and oil addicition herald earth's new epoch: The Anthropocene. Science News. August 24, 2016. Retrieved May, 2017, from http://dx.doi. org/10.1126/science.aah7220

Walker, M., Gibbard, P. \& Lowe, J. 2015. Comment on When did the Anthropocene begin? A mid-twentieth century boundary level is stratigraphically optimal by Jan Zalasiewicz et al. (2015), Quaternary International, 383, 196203. Quaternary International 383: 204-207. https://doi. org/10.1016/j.quaint.2015.04.007

Waters, C. N., Zalasiewicz, J., Summerhayes, C. et al. 2016. The Anthropocene is functionally and stratigraphically distinct from the Holocene. Science 351: aad2622. https://doi. org/10.1126/science.aad2622

Waters, C. N., Zalasiewicz, J. A., Williams, M., Ellis, M. A. \& Snelling, A. M. (Eds.) 2014. A stratigraphical basis for the Anthropocene. The Geological Society of London, London.

Williams, M., Zalasiewicz, J., Haff, P. K., Schwägerl, C., Barnosky, A. D. \& Ellis, E. C. 2015. The Anthropocene biosphere. The Anthropocene Review 2: 196-219. http:// dx.doi.org/10.1177/2053019615591020 
Zalasiewicz, J., Waters, C. N., Williams, M. et al. 2015. When did the Anthropocene begin? A mid-twentieth century boundary level is stratigraphically optimal. Quaternary International 383: 196-203. https://doi.org/10.1016/j. quaint.2014.11.045

Zalasiewicz, J., Waters, C. N., Wolfe, A. P. et al. 2016a. Finney \& Edwards article. GSA Today 27: e36-e37.

Zalasiewicz, J., Waters, C. N., Wolfe, A. P. et al. 2017. Making the case for a formal Anthropocene Epoch: an analysis of ongoing critiques. Newsletters on Stratigraphy 50: 205-226. https://doi.org/10.1127/nos/2017/0385
Zalasiewicz, J., Williams, M., Fortey, R. et al. 2011a. Stratigraphy of the Anthropocene. Philosophical Transactions of the Royal Society A 369: 1036-1055. https://doi.org/10.1098/ rsta.2010.0315

Zalasiewicz, J., Williams, M., Haywood, A. \& Ellis, M. $2011 b$. The Anthropocene: a new epoch of geological time? Philosophical Transactions of the Royal Society A 369: 835-841. https://doi.org/10.1098/rsta.2010.0339

Zalasiewicz, J., Williams, M., Waters, C. N. et al. 2016b. Scale and diversity of the physical technosphere. The Anthropocene Review 4: 9-22. http://dx.doi.org/10.1177/2053019616677743 
Appendix. Press release of the University of Leicester on the Meeting of the Anthropocene Working Group held at Cape Town, South Africa, during the 35th International Geological Congress (http://www2.le.ac.uk/offices/press/press-releases/2016/ august/media-note-anthropocene-working-group-awg).

\section{Media note: Anthropocene Working Group (AWG)}

\section{Posted at Aug 29, 2016 01:11 PM}

The Working Group on the "Anthropocene" (AWG), which includes University of Leicester geologists, will provide its summary of evidence and its provisional recommendations on a potential new geological time interval at the 35th International Geological Congress in South Africa between 27 August-4 September

\section{Please see the below notice for more information:}

This international scientific body (that includes the University of Leicester geologists Jan Zalasiewicz, Mark Williams and honorary chair, the British Geological Survey geologist Colin Waters, and archaeologist Matt Edgeworth), has been active since 2009, analysing the case for formalization of the Anthropocene, a potential new epoch of geological time dominated by human impact on the Earth. The AWG is about to present its preliminary findings and recommendations at the International Geological Congress in Cape Town, at the same time indicating the range of voting opinion within the group on the major questions surrounding the Anthropocene. It will also map out a route towards a formal proposal on formalization, and indicate work that still needs be done to effect this.

Majority current opinion on the group indicates the following:

- The Anthropocene concept, as articulated by Paul Crutzen and Eugene Stoermer in 2000, is geologically real. The phenomenon is of sufficient scale to be considered as part of the International Chronostratigraphic Chart, more commonly known as the Geological Time Scale.

- Majority AWG opinion is for assignation as an Epoch/Series. This option is preferred over either a lower rank (e.g. Age/Stage, i.e. as a subdivision of the Holocene) or a higher rank such as a Period or Era. In such a step, and in common with all other geological time units, the Anthropocene would comprise both a "pure time" unit (an Anthropocene Epoch) and an equivalent unit of strata (an Anthropocene Series).

- If the Anthropocene is adopted as an Epoch, this would mean that the Holocene has terminated, but that we remain within the Quaternary Period and Cenozoic Era.

- Human impact has left discernible traces on the stratigraphic record for thousands of years - indeed, since before the beginning of the Holocene. However, substantial and approximately globally synchronous changes to the Earth System most clearly intensified in the "Great Acceleration" of the mid-20th century. The mid-20th century also coincides with the clearest and most distinctive array of signals imprinted upon recently deposited strata.

- Hence, the mid-20th century represents the optimal beginning of a potential Anthropocene Epoch (and, simultaneously, the base of the Anthropocene Series).

- Changes to the Earth System that characterize the potential Anthropocene Epoch include marked acceleration to rates of erosion and sedimentation, large-scale chemical perturbations to the cycles of carbon, nitrogen, phosphorus and other elements, the inception of significant change to global climate and sea level, and biotic changes such as unprecedented levels of species invasions across the Earth. Many of these changes are geologically long-lasting, and some are effectively irreversible.

- These and related processes have left an array of signals in recent strata, including plastic, aluminium and concrete particles, artificial radionuclides, changes to carbon and nitrogen isotope patterns, fly ash particles, and a variety of fossilizable biological remains. Many of these signals will leave a permanent record in the Earth's strata.

- The Anthropocene beginning might conceivably be defined by a Global Standard Stratigraphic Age (GSSA), i.e. a numerical age that can be expressed as a calendar date such as 1945 . Or more, conventionally it could be defined by a Global boundary Stratotype Section and Point (GSSP), which is more colloquially a "golden 
spike", and is a physical reference point in strata at one carefully selected place. Majority opinion on the AWG is to seek and choose a candidate GSSP, as this is the most familiar and widely accepted method of defining geological time units.

- The AWG has already begun the process of identification of potential GSSPs, by initial analysis of the general environments in which the best combinations of stratigraphic signals may be found (e.g. undisturbed lake or marine sediments, annually banded coral skeletons, polar snow/ice layers, speleothems and so on).

- This will lead to selection of sites for sampling and further analysis, to provide full descriptions of relevant signals in the strata, a process that we hope will lead to the identification of one or more suitable candidate sites for a GSSP. We would hope to complete this process over the next 2-3 years.

- This would then form the basis for the preparation of a formal proposal, to our immediate parent body, the Subcommission on Quaternary Stratigraphy (SQS), on defining a formal Anthropocene unit. If the SQS recommends this by supermajority vote, the proposal will go on to its parent body, the International Commission on Stratigraphy (ICS) to be voted on, with any vote in favour still needing to be ratified by the Executive Committee of the International Union of Geological Sciences (IUGS).
- If all of these conditions can be fulfilled, then the Anthropocene would become a formal part of the Geological Time Scale.

\section{Results of AWG Vote (35 members):}

1. Is the Anthropocene stratigraphically real? For: 34, Against: 0, Abstain: 1

2. Should the Anthropocene be formalised? For: 30, Against: 3, Abstain: 2

3. Hierarchical level of the Anthropocene? Era: 2, Period: 1.5, Epoch: 20.5, Sub-epoch: 1, Age: 2, Sub-age: 0, None: 1, Uncertain: 3, Abstain: 4

4. Base/beginning of the Anthropocene? $\sim 7 \mathrm{ka:} 0$, $\sim 3 \mathrm{ka}$ : 1.3, 1610 Orbis: 0, 1800: 0, 1950: 28.3, 1964: 1.3, Diachronous: 4, Uncertain: 0, Abstain: 0

5. GSSA .v. GSSP? GSSP: 25.5, GSSA: 1.5, Uncertain: 8

6. What is the Primary Signal? aluminium: 0, plastic: 3 , fuel ash particles: 2 , carbon dioxide concentration: 3 , methane concentration: 0 , carbon isotope change: 2 , oxygen isotope change: 0 , radiocarbon bomb spike: 4, Plutonium fallout: 10, Nitrate concentration / nitrogen isotope change: 0, Biostratigraphic: extinction/ assemblage change: 0 , Other (lead, persistent organic pollutants, technofossils): 3 , Uncertain: $2, \mathrm{Ab}-$ stain: 6 . 